\title{
MASIFIKASI PENDIDIKAN KONSTITUSI SEBAGAI PROTEKSI HAK KEBINEKAAN DI ERA PANDEMI COVID-19
}

\author{
Abdul Wahid \\ Fakultas Hukum Universitas Islam Malang \\ Jalan MT Haryono 193, Kelurahan Dinoyo, Kota Malang, 65144 \\ Email: visibos@gmail.com \\ Sunardi \\ Fakultas Hukum Universitas Islam Malang \\ Jalan MT Haryono 193, Kelurahan Dinoyo, Kota Malang, 65144 \\ dr.sunardis@yahoo.com \\ Dwi Ari Kurniawati \\ Fakultas Agama Islam Universitas Islam Malang \\ Jalan MT Haryono 193, Kelurahan Dinoyo, Kota Malang, 65144 \\ Email: dwiarik@gmail.com
}

\begin{abstract}
The constitution is the basic foundation or fundamental juridical norms governing the life of the nation and state in any condition, including when facing the Covid-19 pandemic. The urgency of this constitution will be felt by every citizen through the process of education (learning). Considering that the condition of the people affected by the Covid-19 pandemic is very pluralistic, while every citizen constitutionality has the right to diversity, then every party, especially the education providers to massive constitutional education, which this model is idealized can uphold social justice and prevent disparity and radicality in the community.

Keywords: Massification, Constitutional Education, Protection of Diversity Rights
\end{abstract}

\begin{abstract}
ABSTRAK
Konstitusi merupakan pijakan dasar atau norma yuridis fundamental yang mengatur kehidupan berbangsa dan bernegara dalam kondisi apapun, termasuk saat menghadapi pandemi Covid-19. Urgensinya konstitusi ini akan bisa dirasakan oleh setiap warga negara melalui proses pendidikan (pembelajaran). Mengingat kondisi masyarakat yang terkena pandemi Covid-19 ini sangat pluralistik, sementara setiap warga negara secara konstitusionalitas mempunyai hak atas kebinekaan, maka setiap pihak, khususnya kalangan penyelenggara pendidikan untuk melakukan masifikasi pendidikan konstitusi, yang model ini diidealisasikan dapat menegakkan keadilan sosial dan mencegah disparitas dan radikalitas di tengah masyarakat.

Kata kunci: Masifikasi, Pendidikan Konstitusi, Proteksi Hak Kebhinekaan

\section{PENDAHULUAN}

Manusia, negara, dan konstitusi merupakan ketiga hal yang dari segi nama berbeda, namun dari segi kedudukan, ketiganya bisa saling bertemu dalam dan dengan kedudukannya masing-masing. Meski

demikian, manusia merupakan subyek strategis yang menentukan eksistensi dan keberlanjutan negara dan konstitusi. Dari situlah menunjukkan betapa urgensinya kehadiran manusia dalam kehidupan bernegara dan berkonstitusi. Manusia yang memainkan perannya dengan benar, yakni
\end{abstract}


benarnya bepijak pada norma peraturan perundang-undangan, maka yang berdampak terhadap kehidupan negara atau masyarakat sangatlah besar.

Camilo Jose Cela (1916-2002), penulis Spanyol yang juga peraih Nobel Sastra 1989 mengingatkan, bahwa ada dua jenis manusia: satu yang mengukir sejarah dan satu lagi yang memikul beban akibatnya. ${ }^{1}$ Peraih Nobel ini sebenarnya mengingatkan, bahwa setiap manusia dalam menjalani hidupnya haruslah memahami dua aspek penting atas peran atau aktifitas yang dilakukannya. Dalam pandangan penulis itu, manusia diingatkan tentang dua hal penting yang idealisasinya harus selalu mengikuti peran atau aktifitas yang dilakukannya. Semakin strategis atau fundamental (asasi) peran yang ditunjukkannya, maka semakin besar pula pengaruhnya dalam ranah dimana dirinya berperan.

Saat yang dimainkan dalam peran itu berkaitan dengan pendidikan konstitusi, tentu tidak sulit direlasikan keterkaitannya, bahwa siapapun yang memainkan peran dalam penyelenggaraan pendidikan konstitusi, apa yang diperbuatnya ini tentu dapat berpengaruh terhadap konstruksi demokrasi atau penegakan hak tertentu yang sudah digariskan secara konstitusionalitas.
Terkadang seseorang atau sekumpulan orang yang tergabung dalam komunitas penyelenggara pendidikan konstitusi bersikap abai terhadap pengaruh atau dampak atas perbuatan atau kebijakan yang diterapkannya. Ketika kebijakan soal hak kebinekaan misalnya berhasil diterapkan (diimplementasikan), langsung dijadikan standar utama kalau proteksi terhadap hak konstitusionalitaas diasumsikannya telah sukses memenuhi aspirasi rakyat, yang seolah hak rakyat sudahcukup dipenuhi dengan keterlibatannya di seremonialitas politik, padahal masih banyak kepentingan asasinya terabaikan.

Di era pandemi Covid-19 ini, setiap subyek bangsa, termasuk kalangan subyek Pendidikan dituntut menunjukkan perannya, bahwa beragam kesulitan yang diderita bangsa akibat Covid-19, dapatlah diatasi dengan mengedepankan prinsip egalitarian demi mendukung terwujudnya hak asasi rakyat, meskipun mereka berkeragaman (berkebinekaan). Diduga masih ada saja pihakpihak atau kelompok tertentu yang belum memahami kebinekaan itu, sehingga perlakuan terhadap masyarakat atau korban yang terkena dampak Covid-19 tidaklah manusiawi, egaliter, dan berkeadilan. Keragaman tidaklah atau kurang dihormat sebagai hak konstitusionalitas.

Lukman Saidi, (2011), Belajar Sejarah dari Negarawan, Javamedia, Jakarta, hlm, 23. 


\section{PEMBAHASAN}

\section{Konstruksi Pendidikan Konstitusi}

Pendidikan dalam arti praktek disebut suatu proses pemindahan atau transformasi pengetahuan ataupun pengembangan potensipotensi yang dimiliki subjek didik untuk mencapai perkembangan secara optimal, serta membudayakan manusia melalui transformasi nilai-nilai yang utama. ${ }^{2} 600$ tahun sebelum Masehi, telah dinyatakan orang Yunani, bahwa pendidikan ialah usaha manusia untuk menjadi manusia. Ada dua kata yang penting dalam kalimat itu, pertama "membantu" dan kedua "manusia". Manusia perlu dibantu agar menjadi manusia. Seseorang dapat dikatakan telah menjadi manusia bila telah memiliki nilai (sifat) kemanusiaan. Hal ini menunjukkan bahwa tidaklah mudah menjadi manusia. Karena itulah sejak dahulu manusia sering gagal menjadikan dirinya sebagai manusia. Jadi, tujuan mendidik ialah memanusiakan manusia. Agar tujuan itu dapat dicapai dan agar progam dapat disusun maka cici-ciri manusia yang telah menjadi manusia itu haruslah jelas. ${ }^{3}$ Suatu makna Pendidikan yang berelasi dengan sisi filosofis dan etis, yakni suatu proses edukasi yang melahirkan manusia sebagai manusia, dan bukan sebagai makhluk lainnya.
Dalam pasal 3 Undang-undang Nomor 20 Tahun 2003 tentang Sistem Pendidikan Nasional, bahwa pendidikan nasional berfungsi mengembangkan kemampuan dan membentuk watak serta peradaban bangsa yang bermartabat dalam rangka mencerdaskan kehidupan bangsa, bertujuan untuk berkembangnya potensi peserta didik agar menjadi manusia yang beriman dan bertakwa kepada Tuhan Yang Maha Esa, berakhlak mulia, sehat, berilmu, cakap, kreatif, mandiri, dan menjadi warga negara yang demokratis serta bertanggung jawab.

Pijakan UU Sistem Pendidikan Nasional itu menunjukkan, bahwa dunia pendidikan bukan sekedar menghasilkan manusia yang trampil atau pintar. Sosok demikian belum cukup atau baru separuh jalan untuk diandalkan membangun dan mencerahkan masyarakat dan bangsa. Dari segi sisi kemajuan Iptek, barangkali syarat pintar dan trampil menjadi syarat privilitas yang menentukan, akan tetapi syarat fundamental yang menentukan keberlanjutan dan pencerahan peradaban atau bangunan kuktur sangat ditentukan oleh bagaimana penyelenggaraan pendidikan bisa menghasilkan sosok pengabdi kebenaran atau manusia berkarakter pejuang, yang idealisasi edukasi ini identik dengan merhubungan dengan terbentuknya sosok

2 Chabib Thoha, (1996), Kapita Selekta Pendidikan Islam, Pustaka Pelajar, Yogyakarta, hlm. 98-99

3 Ahmad Tafsir, (2006), Filsafat Pendidikan Islam, Remaja Rosdakarya, Bandung, hlm, 33. 
manusia yang memahami dan berperilaku yang menunjukkan dirinya sebagai manusia.

Sejalan dengan makna dan idealiaasi eukasi tersebut, Kiai Sahal Mahfud juga menyebut, bahwa pendidikan sejatinya merupakan usaha sadar yang membentuk watak dan perilaku secara sistematis, terencana dan terarah, yang berarti substansi privilitas at-tarbiyah ini tak hanya terletak pada transformasi knowledge, tetapi juga berelasi dengan masalah character building. ${ }^{4}$ Dalam ranah ini jelas, bahwa sosok manusia terdidik yang dihasilkan melalui proses pendidikan bukan hanyalah yang berpengetahuan, tetapi juga menunjukkan karakteristiknya terbentuk dengan benar.

Brubacher lebih menguatkan, bahwa "education is the organized development and equipment of all the powers of a human being, moral, intellectual and physical, by and for their individual and social uses, directed toward the union of these activities with their creator as their final and" pengertian ini bisa diterjemahkan kalau pendidikan merupakan perkembangan yang terorganisir dan kelengkapan dari semua potensi manusia, moral, intelektual maupun jasmani, oleh dan untuk kepribadian andividunya dan kegunaan masyarakatnya, yang diarahkan untuk menghimpun semua aktivitas tersebut bagi tujuan hidupnya yang akhir.5 Pikiran pakar ini menunjukkan, bahwa Pendidikan itu beridealisasi pada pembentukan dan berbagai potensi atau aspek penting dalam diri manusia. Ketika hal ini bisa dibentuk, maka sosok subyek didik yang terbentuk akan menjadi sosok yang mempunyai banyak keunggulan, sehingga saat subyek ini menjalankan perannya di masyarakat, akan bisa memberikan yang terbaik bagi orang lain, bangsa, dan negaranya.

Salah satu substansi yang penting untuk menjadi modal membangun subyek didik tersebut adalah konstitusi. Konstitusi dijadikannya sebagai materi wajib dan unggulnya. Setiap subyek didik atau komunitas pembelajar dari kalangan apapun dapat memulainya dengan mengenal konstitusi. Kata konstitusi ini secara literal berasal dari bahasa Prancis "constituir", yang berarti membentuk. Dalam konteks ketatanegaraan, konstitusi dimaksudkan dengan pembentukan suatu negara atau menyusun dan menyatakan sebuah negara. Konstitusi juga bisa berarati peraturan dasar (awal) mengenai pembentukan negara. ${ }^{6}$

4 Ahmad Fadeli, dkk Pendidikan Islam sebagai pembentuk Karakter Peserta Didik, LKPPI, 15 Agustus, 2015, Malang, hlm, 2.

5 Muhammad Tholhah Hasan, (1987), Islam dalam Perspektif Sosial Budaya, Galasa Nusantara, Jakarta, hlm, 1617.

6 Tim ICCE UIN Jakarta. (2003), Pendidikan Kewargaan (Civic Eduatin) Demokrasi Hak Asasi Manusia Masyarakat Madani, ICCE UIN Syarif Hidayatullah, Jakarta, hlm. 89. 
Menurut Chairil Anwar, konstitusi adalah "fundamental laws", tentang pemerintahan suatu negara dan nilai-nilai fundamentalnya. Adapun menurut Sri Soemantri, konstitusi berarti suatu naskah yang memuat suatu bangunan negara dan sendi-sendi sistem pemerintahan negara. E.C.W Wade, mengatakan bahwa yang dimaksud dengan konstitusi adalah naskah yang memaparkan rangka dan tugas-tugas pokok dari badan-badan pemerintahan suatu negara dan menentukan pokok-pokok cara kerja badan tersebut. ${ }^{7}$ Pemahaman ini menunjukkan kalau konstitusi merupakan norma dasar atau bersifat asasi yang mengatur tentang kedudukan negara, tata cara kehidupan bernegara atau membangun (menyelenggarakan) pemerintahan.

Nilai-nilai fundamental dari konstitusi tersebut di Indonesia termuat dalam Pembukaan dan Pasal 1 UUD NRI 1945, yang keberadaannya menjadi asas utama dalam hukum tata negara Indonesia, yaitu: asas Pancasila, asas negara kesatuan, asas negara kedaulatan dan demokrasi, asas negara hukum, asas permisahan kekuasaan dan cheek and balance. ${ }^{8}$ Sebagian deskripsi substantif kon- stitusi inilah yang membuat Pendidikan konstitusi menjadi penting bagi setiap warga negara.

Setiap penyelenggara kekuasaan atau warga negara harus taat pada perintah konstitusi. Konstitusi sebagai hukum tertinggi suatu negara yang mengatur penyelenggaraan kekuasaan negara dan sebagai jaminan atas hak-hak warga negara, konstitusi memuat beberapa ketentuan pokok sebagai berikut: ${ }^{9}$ organisasi negara, hak-hak asasi manusia dan kewajibannya, prosedur mengubah konstitusi, konstitusi yang juga dapat dipahami sebagai bagian dari social contract (kontrak sosial) yang memuat aturan main dalam berbangsa dan bernegara, menurut Sovernin Lohman harus memuat unsur-unsur sebagai berikut: konstitusi dipandang sebagai perwujudan perjanjian masyarakat (kontrak sosial), Konstitusi sebagai piagam yang menjamin hak-hak asasi manusia dan warga negara sekaligus penentuan batas-batas hak dan kewajiban warga negara dan alat-alat pemerintahannya, Konstitusi sebagai "forma regimenis" yaitu kerangka bangunan pemerintahan. ${ }^{10}$ Tanpa pijakan konstitusi, seseorang dapat dalam perbatan yang merugikan banyak orang, karena yang diperbuatnya lebih banyak yang berpola mengikuti kemauan sendiri, sekoral dan kelompok.

Ibid, hlm. 90.

Ni`matul Huda, (2005), Hukum Tata Negara, RajaGrafindo Persada, Jakarta, hlm, 90-97.

9 Erman Hermawan, (2001), Politik Membela yang Benar, Teori Kritik dan Nalar, Garda Bangsa, Jakarta, hlm. 58

10 Tim ICCE UIN Jakarta, Op.Cit, hlm. 91. 
Kalau dalam diri setiap warga negara mempunyai ilmu pengetahuan mengenai konstitusi atau dalam dirinya ada pengetahuan tentang bagaimana hidup bermasyarakat dan bernegara yang benar dan bertanggunngjawab, maka segala keinginan, beragam pola berperilaku atau menunjukkan sepak terjangnya mempunyai landasan norma etis yang membimbing atau mengarahkannya.

\section{Masifikasi dan Proteksi}

Mewujudkan atau menyukseskan transformasi norma yuridis atau konstitusi di tengah masyarakat, tidak terkecuali komunitas terdidik seperti mahasiswa dan para pemimpin negara, bukanlah pekerjaan yang gampang. Ada pendapat dari Mochtar Kusumaatmadja, bahwa pemahaman hukum yang memadai harus tidak hanya memandang hukum itu sebagai suatu perangkat kaidah dan asas-asas yang mengatur kehidupan manusia dalam masyarakat, tapi harus pula mencakup lembaga (institusi) dan proses yang diperlukan untuk mewujudkan hukum itu dalam kenyataan. ${ }^{11}$ Mewujudkan hukum dalam kenyataan seperti pendapat Mochtar Kusumaatmadja identic dengan meminta kalau norma konstitusi itu tidak boleh "hidup di atas kertas", tetapi harus dipahami dan ditegakkan (disebarkan) secara masif di masyarakat.

Masifikasi itu penting seiring dengan perkembangan konstitusi di negara ini. Artinya perubahan sistem politik dan kekuasaan negara paska terjadinya amandemen UUD 1945 telah membawa angin segar bagi perkembangan cita demokrasi dan konstitusionalisme Indonesia yang salah satunya menyebabkan terjadinya pergeseran kekuasaan supremasi parlemen (parliament supremacy) menuju supremasi konstitusi (constitutional supremacy). Kedaulatan rakyat (people's sovereignty) yang dahulu berada di tangan Majelis Permusyawaratan Rakyat (MPR), kini pun telah berubah menjadi terletak di tangan rakyat. ${ }^{12}$ Pemahaman tentang supremasi konstitusi ini idealisasinya harus menjadi pemahaman asasi dalam diri setiap warga negara.

Berkaitan dengan pemahaman itu, secara tidak langsung Kuntowijoyo menyampaikan gagasannya lebih tajam, bahwa radikalisasi Pancasila terdiri dari lima konsep atau gagasan yaitu: (1) mengembalikan pancasila sebagai ideologi negara; (2) mengganti persepsi dari Pancasila sebagai ideologi menjadi Pancasila sebagai ilmu; (3) mengusahakan Pancasila mempunyai konsistensi dengan produk

11 DPD RI dan Universitas Brawijaya, (2009), Konstruksi Perwakilan Daerah Dalam Sistem Ketatanegaraan Indonesia, Pusat Pengkajian Konstitusi Fakultas Hukum Universitas Brawijaya, Malang, hlm. 15.

12 Pan Muhammad Faiz, (2012), Mengawal Demokrasi Melalui Constitutional Review, Sembilan Pilar Demokrasi Putusan Mahkamah Konstitusi, Jakarta, hlm. 1 
perundang-undangan, koherensi antarsila, dan korespondensi dengan realitas sosial; (4) Pancasila yang semula melayani kepentingan vertikal menjadi Pancasila yang melayani kepentingan, (5) menjadikan Pancasila sebagai kritik kebijakan negara. ${ }^{13}$ Radikalisasi yang dituntut Kunto ini secara tidak lansung meminta dengan sangat pada setiap subyek pembelajar atau warga negara untuk mengimplementasikan pendidikan konstitusi, yang diantara materi utamanya tentang transformasi dan pembumian ideologis (Pancasila) dalam setiap aktifitas kemasyarakatan dan kenegaraan.

Tuntutan yang disampaikan Kunto itu barangkali seiring berjalannya kesadaran politik warga negara saat memasuki era reformasi 1998, dimana akhirnya disadari bahwa program pendidikan karakter era orde baru tersebut dirasakan sebagai indoktrinasi semata untuk mempertahankan keberlanjutan penguasaan terhadap bangsa ini oleh pemimpin saat itu yang bertentangan dengan nilai-nilai demokrasi. Menurut Presiden Ke-3 RI B.J. Habibie euforia reformasi sebagai akibat dari traumatisnya masyarakat terhadap penyalahgunaan kekuasaan masa lalu yang mengatasnamakan Pancasila menyebabkan generasi reformasi menanggalkan segala hal yang dipahaminya sebagai sebagai bagian dari masa lalu dan menggantinya dengan sesuatu yang baru. ${ }^{14}$ Meski mereka dihadapkan dengan tantangan aspek kesejarahan, namun tantangan bangsa, termasuk tantangan di ranah ideologi dan konstitusi realitasnya berjalan seiring dengan perkembangan masyarakat tingkat regional, nasional, dan global.

Tidak sulit dibaca dan dipahami oleh masyarakat atau bangsa ini, khususnya kalangan pembelajar, bahwa salah satu persoalan yang dinilai banyak pihak sedang mengkhawatirkan bangsa yang sedang dihadapkan dengan wabah Covid-19 adalah soal ketahanan rakyat di berbagai bidang strategisnya, khususnya ketahanan sosial, kesehatan, ekonomi, dan pangan. Mereka takut rakyat negeri ini akan mengalami krisis multidimensi serius akibat Covid-19. Jika wabah ini berlangsung lama, mereka lebih khawatir lagi dengan ketersediaan sumberdaya strategisnya di masa depan.

Laporan Kompas.Com menyebutkan (menguatkan kekhawatiran), bahwa dalam beberapa bulan ke depan, bencana kelaparan dalam skala besar diperkirakan akan melanda seluruh dunia.

13 Kuntowijoyo dalam Hajriyanto Y Tohari, "Strategi Pembudayaan Nilai-Nilai Pancasila di Bidang Sosial dan Politik Dalam Perspektif ke-Indonesiaan", dalam Pusat Studi Pancasila UGM, Prosiding Kongres Pancasila V 2013 (Strategi Pembudayaan Nilai-Nilai Pancasila Dalam Menguatkan Semangat ke-Indonesia-an), Yogyakarta, 31 Mei1 Juni 2013, hlm. 36.

14 Sekretariat Jenderal MPR, (2012), Presiden Bicara Pancasila, Sekjen MPR, Jakarta, hlm. 49 
Perserikatan Bangsa-Bangsa (PBB) memperingatkan bahwa bencana kelaparan tersebut adalah imbas dari pandemi virus corona yang saat ini masih melanda seluruh dunia. Melansir CNN, pada 22/4/2020, Direktur Eksekutif Program Pangan Dunia (WFP) David Beasley memprediksi bahwa skenario terburuk dari bencana kelaparan ini akan melanda sedikitnya tiga lusin negara. Sementara itu, saat ini sepuluh dari negara-negara itu sudah memiliki lebih dari 1 juta orang diambang kelaparan. David menyebut bahwa konflik, resesi ekonomi, penurunan bantuan dan jatuhnya harga minyak dunia sebagai faktor yang mungkin menyebabkan krisis pangan dan membutuhkan tindakan cepat untuk mencegah bencana itu. "Saat kita menangani pandemi Covid-19, kita juga berada diambang pandemi kelaparan. Ada juga bahaya nyata bahwa lebih banyak orang berpotensi meninggal akibat dampak ekonomi Covid-19 daripada dari virus itu sendiri, ${ }^{15}$

WFP sebelumnya telah memperingatkan bahwa pada 2020 akan menjadi tahun yang sulit bagi banyak negara yang dilanda oleh kemiskinan atau perang. Sebanyak 135 juta orang terancam menghadapi krisis kelaparan atau lebih buruk lagi. Angka tersebut ditambah dengan 821 juta orang yang saat ini tengah dilanda kelaparan kronis, dapat mendorong lebih dari 1 miliar orang ke dalam situasi yang mengerikan. Badan itu mengidentifikasi 55 negara yang paling berisiko terjerumus ke dalam kelaparan dalam laporan tahunannya tentang krisis pangan yang dirilis minggu ini. WFP juga memperingatkan bahwa sistem perawatan kesehatan negara-negara yang rapuh ini tidak akan mampu mengatasi dampak virus corona. ${ }^{16}$

Atas dasar fenomena itu, barangkali tanpa menjalankan strategi dan langkah yang lebih terarah dalam tanggap darurat terhadap kepentingan asasi yang nyata atau berlandaskan peta permasalahan yang sebenarnya, bukan tidak mungkin dampak pandemi Covid19 dapat memicu ancaman kesulitan serius rakyat baik di tingkat pusat maupun daerah, terutama rakyat kecil yang ada di wilayah pinggiran atau pedalaman.

Dapat ditemukan sejumlah realitas, bahwa secara khsus di sektor pangan misalnya, barangkali bukan akibat kurangnya stok pangan, atau gangguan logistik dan distribusi, tapi akibat masyarakat atau sekelompok masyarakat bawah (lower class) yang tidak sanggup lagi membeli bahan pangan, yang nota bene terjadinya reduksi kemampuan atau keberdayaan ekonomi (economical

\footnotetext{
15 Jawahir Gustav Rizal, (24/4/2020), Ancaman Kelaparan dan Krisis Pangan Global Setelah Pandemi Corona, akses 29 April 2020, Kompas.com., https://www.kompas.com/tren/read/2020/04/24/142919365/ancaman-kelaparandan-krisis-pangan-global-setelah-pandemi-corona,

16 Ibid.
} 
empowering). Apalagi di lain sisi, sejumlah pengusaha juga memberi sinyal kalau kemampuan keuangan perusahaan mereka untuk bertahan di tengah badai Covid -19 maksimal tinggal beberapa bulan ke depan. Kalau seperti ini, maka yang berat tentulah kelompok masyarakat tidak mampu. Jika perusahaan tidak lagi bisa bertahan, rasanya berat bagi masyarakat kecil untuk mempertahankan dirinya. Disinilah kebinekaan itu akhirnya merambah di sektor perekonomian (pendapatan) hingga ke daerah-daerah, yang bukan tidak mungkin bisa menyulut terjadinya gesekan atau konflik dan kekerasan, apalagi jika ada kekuatan politik tertentu yang bukan menghadirkan kondisi kedamaian, melainkan kekacauan (chaos).

Hal itu berarti dapat dipahami dari sudut pandang pemberdayaan politik, bahwa tujuan desentralisasi dapat dilihat dari dua sisi yaitu pemerintah daerah dan pemerintah pusat. Tujuan desentralisasi dari sisi pemerintah daerah adalah untuk mewujudkan political equality, local accountability dan local responsiveness. Sementara itu, tujuan desentralisasi dari sisi pemerintah pusat adalah mewujudkan political education, provide training in political leadership dan create political stability. ${ }^{17}$ Desentralisasi ini sejatinya juga bertujuan untuk meningkatkan kemampuan pemerintah daerah dalam menyediakan public goods and services dan untuk meningkatkan efisiensi dan efektifitas pembangunan ekonomi di daerah. Tuntutan demikian dimulai dengan memasifikasi pendidikan konstitusi yang diantaranya menekankan tentang proteksi kebinekaan.

Tjosvold sebagaimana dikutip dari bukunya Sadu Wasistiono mengemukakan, bahwa memenuhi hajat hidup masyarakat baik sebagai kewajiban maupun sebagai kehormatan merupakan dasar bagi terbentuknya masyarakat yang manusiawi. ${ }^{18}$ Artinya, jika konstruksi Pemda dinilai sebagai bangunan yang kuat, maka salah satu standar eksaminasinya terletak pada realitas keberhasilanya dalam mewujudkan otonomi daerah yang "memanusiakan" masyarakat di daerah. Pemanusiaan ini dapat terbaca keberhasilannya ketika realitas kebinekaan masyarakat terproteksi dengan baik.

Keberhasilan pelaksanaan kebijakan (pembangunan), menurut Hill dan Hupe mengharuskan kepatuhan dengan arahan dan tujuan peraturan perundang-undangan, pencapaian indikator keberhasilan tertentu, dan membaiknya iklim politik di seluruh program. ${ }^{19}$ Ketika di daerah

7 Syarif Hidayat, "Desentralisasi untuk Pembangunan Daerah", Jentera, Peraturan Daerah edisi 14 Tahun IV, Oktober-Desember 2006, hlm. 87.

18 Sadu Wasisto, (2003), Kapita Selekta Manajemen Pemerintahan Daerah, Fokus Media, Bandung, hlm 42.

19 Mulawarman Rais, (2011), Politik Membangun Otonomi Daerah, Himas, Jakarta, hlm. 2. 
banyak kebijakan atau produk yuridis dari pusat yang gagal "membumi" atau dilawan gara-gara tidak sejalan dengan kepentingan asasi masayarakat di daerah, atau dianggap inkonstitusionalitas karena tidak mengapresiasi atau mengakomodasi kondisi kebeniekaan, maka tentu yang harus dievaluasi atau bahkan "digugat" secara serius adalah kinerja para pendidik konstitusi, khususnya di tingkat elitisnya. Mereka layak dinilai belum mampu menerjemahkan asipirasi rakyat yang berkarakteritik pluralistik.

Fenomena seperti itu mengindikasikan kalau hak kebinekaan dalam penyelenggaran kehidupan kebernegaan belum berhasil. Kalau belum berhasil seperti ini dapat diinterpretasikan, bahwa tingkat kesadaran konstitusi di ranah ini masih harus terus dibangun. Setiap subyek sosial, khususnya komunitas elitisnya yang juga berlatar pluralistik atau berkebinekaan, adalah kelompok yang paling bertanggungjawab terhadap tingkat kesadaran konstitusionalitas masyarakat ini.

Ajakan yang sering disampaikan oleh pimpinan negara untuk bersatu atau Bersama elawan Covid-19 juga dapat dibaca sebagai pesan moral kebangsaan yang sangat agung, yang menunjukkan, bahwa tidak ada hal mustahil yang tidak bisa diatasi atau diselesaikan jika dilakukan dengan mengutamakan semangat dan aksi bersama atau bersatu dalam kebinekaan untuk memproteksi hak kebinekaan, khususnya dalam menghadapi serangan Covid-19.

Sebagai bukti, negara ini pernah atau berkalikali menghadapi krisis, khususnya krisis ekonomi, tetapi faktanya tetap bisa keluar dari masalah. Keragaman sosial, agama, dan ekonomi mampu membawa kesatuan hidup, sehingga bisa memecahkan masalah serius bangsa dengan semangat dan gerakan nasionalitas dalam keberagaman. Syed Sajjad Husain dan Syed Ali Ashraf menyebut kesejatian pendidikan (Islam) adalah suatu pendidikan yang melatih perasaan subyek didik dengan cara begitu rupa sehingga dalam sikap hidup, tindakan, keputusan, dan pendekatan mereka terhadap segala jenis pengetahuan, mereka dipengaruhi sekali oleh nilai spritual dan sangat sadar akan nilai etis Islam. ${ }^{20}$ Berpijak pada pandangan ini, makin jelas menunjukkan, bahwa dengan pendidikan konstitusi, masyarakat, khususnya yang sedang dalam posisi mapan (ekonomi) secara ekonomi maupun politik (kekuasaan) akan terbimbing untuk menjadi para pejuang yang giat memberikan yang terbaik untuk masyarakat yang sedang terdampak atau bermasalah dengan pandemi Covid-19. Disinilah penguatan masifikasi pendidikan konstitusi menjadi pilihannya. Jika banyak subyek ekonomi dan

20 Syed Sajjad Husain dan Syed Ali Ashraf, (1986) Crisis Muslim Education., Terj. Rahmani Astuti, Krisis Pendidikan Islam, Risalah, Bandung, hlm. 2. 
politik yang memahami konstitisi dengan benar, maka mereka akan lebih cerdas dan bernurani dalam menjalankan keunggulan yang dimiliki atau dipercayakan padanya di tengah kebinekaan masyarakat yang sedang dieksaminasi oleh pandemi Covid-19.

Para pembelajar konstitusi itu juga akan terdorong mengaktualisasikan perannya dalam konstruksi tujuan bernegara yang benar yang secara konklutif dapat dikategorikan menjadi tiga tujuan, yaitu: 1) memberikan pembatasan sekaligus pengawasan terhadap kekuasaan politik, 2) melepaskan kontrol kekuasaan dari penguasa sendiri, dan 3) memberikan batasan-batasan ketetapan bagi para penguasa dalam menjalankan kekuasaanya. Ketiganya ini setidaknya menjadi pengingat, penyemangat, atau kekuatan moral kebangsaan yang tertuju pada atau demi proteksi kepentingan asasi masyarakat dari kemungkinan munculnya praktik diskriminasi dan intoleransi karena faktor keragaman.

Deskripsi itu menunjukkan, bahwa masifikasi para pembelajar konstitusi di tengah masyarakat akan memprevensi munculnya praktik-praktik inkonstitusionalitas. Pihakpihak yang bermaksud merekahkan konstruksi Negara Kesatuan Republik Indonesia (NKRI) dengan dalih penanganan pandemi Covid-19 tidak berkeadilan dan berkemanusiaan sebagai wujud proteksi hak kebinekaan, dengan sendirinya akan gagal ketika di tengah masyarakat semakin banyak yang menyadari dan memahami urgensinya konstititusi.

\section{KESIMPULAN}

Secara general setiap bangsa dan negara di dunia ini mempunyai konstitusi, diantaranya Indonesia. Konstitusi (di Indonesia disebut juga dengan Undang-Undang Dasar Negara Republik Indonesia tahun 1945) merupakan pijakan dasar atau norma yuridis fundamental yang mengatur kehidupan berbangsa dan bernegara dalam kondisi apapun, termasuk saat menghadapi pandemi Covid-19. Urgensinya konstitusi ini akan bisa dirasakan oleh setiap warga negara melalui proses pendidikan (pembelajaran), karena dari ranah ini, terjadi transformasi pengetahuan dan pemahaman, yang membuatnya bisa menyadari makna dan impelementasi kewajiban dan hak-hak asasi.

Berpijak pada kondisi masyarakat Indonesia yang terkena pandemi Covid-19 sangat pluralistik, sementara setiap warga negara secara konstitusionalitas mempunyai hak atas kebinekaan, maka setiap pihak, khususnya kalangan penyelenggara pendidikan untuk melakukan masifikasi (perluasan) pendidikan konstitusi, yang model ini diidealisasikan dapat menegakkan banyak kepentingan asasi masyarakat.

\section{DAFTAR PUSTAKA}

\section{Buku}

Ahmad Tafsir, 2006, Filsafat Pendidikan Islam, Bandung: Remaja Rosdakarya. 
Chabib Thoha, 1996, Kapita Selekta Pendidikan Islam, Yogyakarta: Pustaka Pelajar.

DPD RI dan Universitas Brawijaya, 2009, Konstruksi Perwakilan Daerah Dalam Sistem Ketatanegaraan Indonesia, Malang: Pusat Pengkajian Konstitusi Fakultas Hukum Universitas Brawijaya.

Erman Hermawan, 2001, Politik Membela yang Benar, Teori Kritik dan Nalar, Jakarta: Garda Bangsa.

Lukman Saidi, 2012, Belajar Sejarah dari Negarawan, Jakarta: Javamedia.

Muhammad Tholhah Hasan, 1987, Islam dalam Perspektif Sosial Budaya, Jakarta: Galasa Nusantara.

Mulawarman Rais, 2011, Politik Membangun Otonomi Daerah, Jakarta: Himas

Ni`matul Huda, 2005, Hukum Tata Negara, Jakarta: RajaGrafindo Persada.

Pan Muhammad Faiz, 2012, Mengawal Demokrasi Melalui Constitutional Review: Sembilan Pilar Demokrasi Putusan Mahkamah Konstitusi.

Sadu Wasisto, 2003, Kapita Selekta Manajemen Pemerintahan Daerah, Bandung: Fokus Media

Sekretariat Jenderal MPR, 2012, Presiden Bicara Pancasila, Jakarta: Sekjen MPR.

Syed Sajjad Husain dan Syed Ali Ashraf, 1986, Crisis Muslim Education., Terj.
Rahmani Astuti, Krisis Pendidikan Islam, Bandung: Risalah.

Tim ICCE UIN Jakarta. 2003, Pendidikan Kewargaan (Civic Eduatin) Demokrasi Hak Asasi Manusia Masyarakat Madani, Jakarta: ICCE UIN Syarif Hidayatullah.

\section{Makalah dan Prosiding}

Ahmad Fadeli, dkk Pendidikan Islam sebagai pembentuk Karakter Peserta Didik, LKPPI, 15 Agustus, 2015, Malang.

Kuntowijoyo dalam Hajriyanto Y Tohari, "Strategi Pembudayaan Nilai-Nilai Pancasila di Bidang Sosial dan Politik Dalam Perspektif ke-Indonesiaan", dalam Pusat Studi Pancasila UGM, Prosiding Kongres Pancasila V 2013 (Strategi Pembudayaan Nilai-Nilai Pancasila Dalam Menguatkan Semangat keIndonesia-an), Yogyakarta, 31 Mei-1 Juni 2013.

Syarif Hidayat, "Desentralisasi untuk Pembangunan Daerah", Jentera: Peraturan Daerah edisi 14 Tahun IV, Oktober-Desember 2006.

\section{Internet}

Kompas.com dengan judul "Ancaman Kelaparan dan Krisis Pangan Global Setelah Pandemi Corona https://www.kompas.com/tren/read/2020/04 /24/142919365/ancaman-kelaparan-dankrisis-pangan-global-setelah-pandemi-corona, akses 29 April 2020. 